Provided for non-commercial research and education use. Not for reproduction, distribution or commercial use.

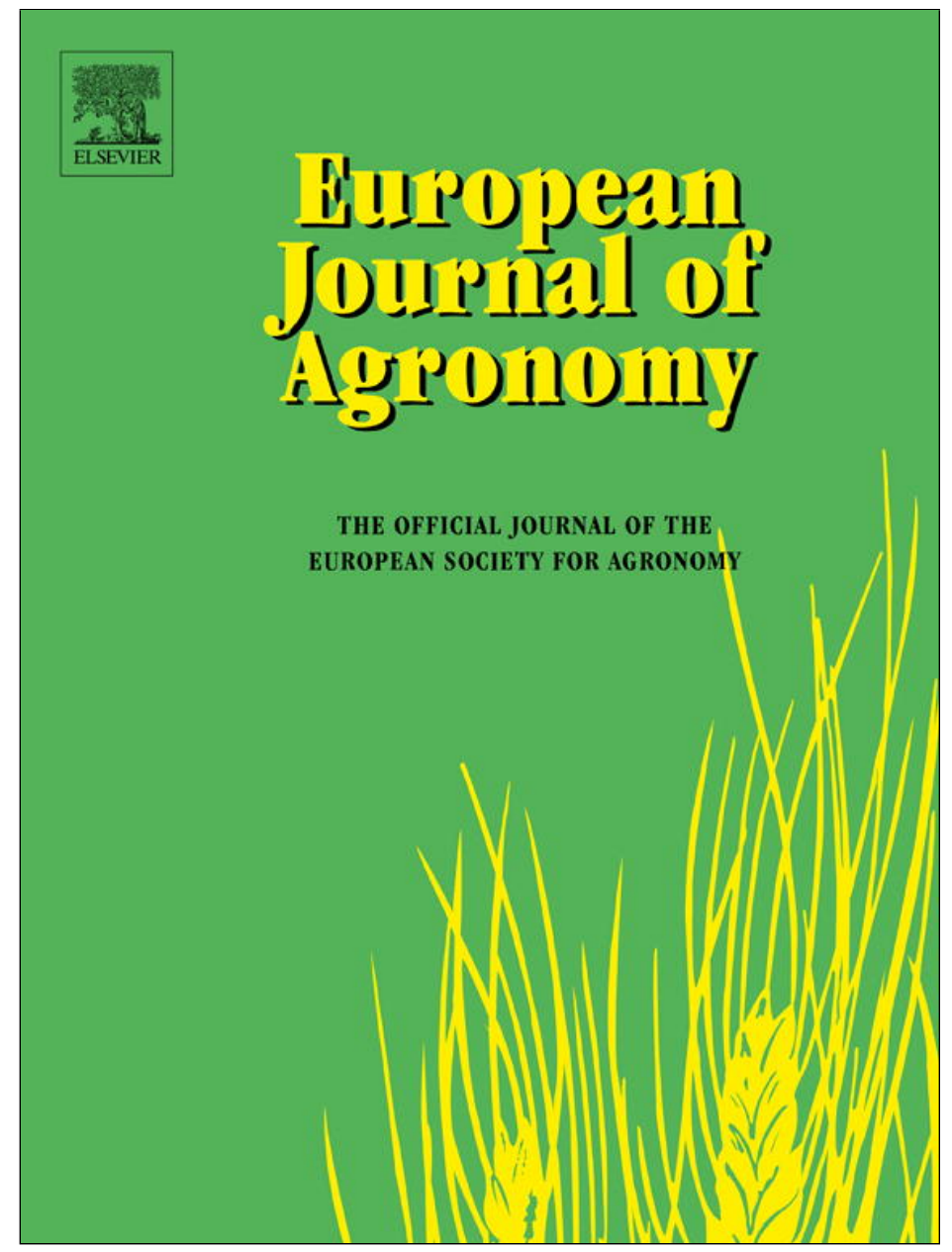

(This is a sample cover image for this issue. The actual cover is not yet available at this time.)

This article appeared in a journal published by Elsevier. The attached copy is furnished to the author for internal non-commercial research and education use, including for instruction at the authors institution and sharing with colleagues.

Other uses, including reproduction and distribution, or selling or licensing copies, or posting to personal, institutional or third party websites are prohibited.

In most cases authors are permitted to post their version of the article (e.g. in Word or Tex form) to their personal website or institutional repository. Authors requiring further information regarding Elsevier's archiving and manuscript policies are encouraged to visit:

http://www.elsevier.com/copyright 


\title{
As durum wheat productivity is affected by nitrogen fertilisation management in Central Italy
}

\author{
Laura Ercoli $^{\mathrm{a}, *}$, Alessandro Masoni ${ }^{\mathrm{b}}$, Silvia Pampana ${ }^{\mathrm{b}}$, Marco Mariotti ${ }^{\mathrm{c}}$, Iduna Arduini $^{\mathrm{b}}$ \\ a Scuola Superiore Sant'Anna, p.zza Martiri della Libertà 33, 56127 Pisa, Italy \\ ${ }^{\mathrm{b}}$ Dipartimento di Scienze Agrarie, Alimentari e Agroambientali, via del Borghetto 80, 56124 Pisa, Italy \\ ${ }^{\mathrm{c}}$ Dipartimento di Scienze Veterinarie, viale delle Piagge 2, 56124 Pisa, Italy
}

\section{A R T I C L E I N F O}

\section{Article history:}

Received 8 May 2012

Received in revised form 26 July 2012

Accepted 13 August 2012

\section{Keywords:}

Triticum durum

$\mathrm{N}$ fertilisation

$\mathrm{N}$ splitting

N source

$\mathrm{N}$ leaching

\begin{abstract}
A B S T R A C T
Optimisation of $\mathrm{N}$ fertilisation is a central issue and goal of applied research in agricultural systems. Site-specific management techniques are needed in order to closely match availability with requirement throughout crop cycle and to reduce as much as possible environmental dispersion of $\mathrm{N}$. Lysimeter experiments were conducted in central Italy in two subsequent seasons to investigate the response of two commercial durum wheat cultivars to different $\mathrm{N}$ fertilisers applied before seeding and at topdressing, and to split applications of $\mathrm{N}$. Grain yield and yield components, $\mathrm{N}$ uptake and $\mathrm{N}$ leaching were determined. Ammonium sulphate (AS) and urea containing the nitrification inhibitor 3,4-dimetihyl pyrazole phosphate (Entec ${ }^{\circledR} 46$ ) were applied before seeding; AS, ammonium nitrate sulphate containing the nitrification inhibitor 3,4-dimetihyl pyrazole phosphate (Entec ${ }^{\circledR} 26$ ), and urea were applied at 5th leaf unfolded stage. Six N-fertiliser treatments with a total $\mathrm{N}$ amount of $180 \mathrm{~kg} \mathrm{~N} \mathrm{ha}^{-1}$ were tested, consisting of splitting application before seeding, at GS15 and GS30 respectively of 0-180-0, 0-90-90, 30-150-0, $30-75-75,60-120-0$ and 60-60-60 $\mathrm{kg} \mathrm{N} \mathrm{ha}^{-1}$. In both years, fertiliser splitting affected durum wheat grain yield and $\mathrm{N}$ concentration; variations due to splitting reached $1 \mathrm{t}$ in grain yield and $7 \mathrm{~g} \mathrm{~kg}^{-1}$ in N concentration of grain, corresponding to $4 \%$ increase in protein content. Highest grain yield, protein concentration, nitrogen use efficiency (NUE), and nitrogen uptake efficiency (NUpE) were obtained with the application of $30 \mathrm{~kg} \mathrm{Nha}^{-1}$ before seeding. The yield advantage was related to higher number of kernels per spike, resulting from higher number of fertile spikelets per spike. Grain yield was not affected by nitrogen source applied before seeding, but was modified by topdressing $\mathrm{N}$ fertiliser. Yield increased by $0.4 \mathrm{t} \mathrm{ha}^{-1}$ with urea, compared to AS and Entec ${ }^{\circledR} 26$, owing to a greater number of kernels per spike. Nitrogen leaching was closely related to rainfall: total amount of $\mathrm{N}$ lost during wheat cycle was almost entirely accounted for $\mathrm{N}$ leaching in winter, before topdressing $\mathrm{N}$ application. As a consequence, the quantity of $\mathrm{N}$ lost by leaching increased with the increase of $\mathrm{N}$ rate applied before seeding, while topdressing fertiliser did not affect losses.
\end{abstract}

(C) 2012 Elsevier B.V. All rights reserved.

\section{Introduction}

Optimisation of mineral $\mathrm{N}$ fertilisation aimed to increase $\mathrm{N}$ use efficiency is a central issue and goal of applied research in agricultural systems. Nitrogen use efficiency of worldwide cereal crops was estimated to be near 33\% (Raun and Johnson, 1999), ranging from 14 to 59\% in wheat (Melaj et al., 2003; López-Bellido et al., 2005); which suggests that current $N$ strategies are extremely inefficient.

Nitrogen use efficiency (NUE) in cereal grain production may be low owing to losses of $\mathrm{N}$ by volatilisation, denitrification and

\footnotetext{
* Corresponding author. Tel.: +39 050883357; fax: +39 050883215.

E-mail address: ercoli@sssup.it (L. Ercoli).
}

leaching. Ammonium-based nitrogen fertiliser products are susceptible to volatilisation losses of nitrogen if surface-applied and not incorporated. Bouwman et al. (2002) estimated that $\mathrm{NH}_{3}$ volatilisation losses from synthetic $\mathrm{N}$ fertilisers applied to both winter and summer crops amounts to $7 \%$ in industrialised countries. In Europe, fertiliser $\mathrm{N}$ losses via denitrification were estimated at $0.2-2.9 \%$ of the $\mathrm{N}$ applied to cereals (Kaiser et al., 1996).

Leaching losses occur when rainfall exceeds crop evapotranspiration and downward water movement through the soil profile takes place, which corresponds to the fall-winter period in humid Mediterranean climate (Arregui and Quemada, 2006). Leaching $\mathrm{N}-\mathrm{NO}_{3}$ losses from durum wheat crop were estimated in central Italy at $21-32 \mathrm{~kg} \mathrm{~N} \mathrm{ha}^{-1} \mathrm{yr}^{-1}$, corresponding to $12-22 \%$ of the total $\mathrm{N}$ applied (Ercoli et al., 2012). Nitrate leaching in a 3-year crop rotation wheat-barley-rapeseed in similar conditions in Spain was 
estimated at $31-35 \mathrm{~kg} \mathrm{Nha}^{-1} \mathrm{y}^{-1}$, or $25-29 \%$ of the total $\mathrm{N}$ applied (Arregui and Quemada, 2006). Thus, as a general rule, $\mathrm{N}$ leaching in Mediterranean climate can be regarded as the greatest source of $\mathrm{N}$ loss and the major determinant of low $\mathrm{N}$ utilisation efficiency.

Durum wheat is widely cultivated throughout the Mediterranean region, where the crop is typically planted in November and harvested at the beginning of July. Heavy rainfall and low crop evapotranspiration rates can be expected between November and March, resulting in higher risk of $\mathrm{N}$ leaching losses. To reduce leaching losses, fertiliser application should aim to match as much as possible the requirement of plant $\mathrm{N}$ with the available nitrogen in soil, minimising the excess of $\mathrm{N}$ in soil useless to the plant. Thus, application should be the latest possible compatible with the stage of development that still permits rapid $\mathrm{N}$ uptake, in order to reduce the opportunities for $\mathrm{N}$ losses of unused $\mathrm{N}$ (Raun et al., 2008).

A number of experiments in winter cereal have shown that split applications of $\mathrm{N}$ fertiliser involving equal quantities of $\mathrm{N}$ applied before and after seeding are agronomical strategies to improve $\mathrm{N}$ utilisation efficiency (Alcoz et al., 1993; Delogu et al., 1998; LópezBellido et al., 2005, 2012; Dilz, 1988). Sowers et al. (1994) and Strong (1995) found that the $\mathrm{N}$ fertiliser applied in autumn, owing to increased $\mathrm{N}$ leaching, had a lower efficiency than when the nitrogen was splitted in fall and spring. Garrido-Lestache et al. (2004) observed that timing and splitting of $\mathrm{N}$ fertiliser influenced grain protein content, which peaked when half or one-third of the $\mathrm{N}$ rate $\left(150 \mathrm{~kg} \mathrm{~N} \mathrm{ha}^{-1}\right.$ ) was applied at stem elongation, and in some cases when $\mathrm{N}$ was applied only at tillering. However, the effect of splitting $\mathrm{N}$ rate on grain quality was unclear in other studies (Ayoub et al., 1994; Garrido-Lestache et al., 2005). Fuertes-Mendizábal et al. (2010) found that the splitting of the same $\mathrm{N}$ rate in three amendments (stages GS20, GS30, and GS37, according to Zadoks scale) instead of two (stages GS20 and GS30) did not modify grain yield but improved grain protein content, indicating that a late $\mathrm{N}$ application may have more impact on $\mathrm{N}$ metabolism and $\mathrm{N}$ remobilisation than on biomass accumulation and grain yield. Ottman et al. (2000) showed higher grain protein contents with the application of high $\mathrm{N}$ rates at anthesis.

Another strategy to reduce $\mathrm{N}$ leaching losses and to increase $\mathrm{N}$ utilisation efficiency is the use of fertilisers releasing reduced and controlled amount of nitric N. Several studies have shown beneficial effects of the use of slow and controlled-release fertilisers, stabilised fertilisers and/or nitrification and urease inhibitors to enhance productivity of agricultural and horticultural crops (Prasad and Power, 1995; Pasda et al., 2001; Carreres et al., 2003). In other studies, however, no positive results have been reported following the application of fertilisers that delay nutrient availability (Cartagena et al., 1995; Diez et al., 1997; Arregui and Quemada, 2008). Inconsistencies in results may appear since soil properties and/or climatic conditions affect both nutrient-release rates from fertilisers and processes leading to leaching and denitrification losses and immobilisation in soil.

The present work was undertaken to determine the effects of different sources of $\mathrm{N}$ fertiliser distributed before seeding and topdressing and split applications of $\mathrm{N}$ on grain yield, yield components, $\mathrm{N}$ uptake and $\mathrm{N}$ leaching of durum wheat, and to identify $\mathrm{N}$ fertiliser and type of splitting that optimised $\mathrm{N}$ uptake and retention in Mediterranean environments.

\section{Material and methods}

Lysimeter experiments were conducted in two successive growing seasons, 2008-2009 and 2009-2010 at the experimental station of the Department of Scienze Agrarie, Alimentari e Agroambientali of the University of Pisa, Italy, that is located at a distance of approximately $10 \mathrm{~km}$ from the sea $\left(43^{\circ} 40^{\prime} \mathrm{N}, 10^{\circ} 19^{\prime} \mathrm{E}\right)$ and $3 \mathrm{~m}$ above sea level. The climate of the site is cold, humid Mediterranean with mean annual maximum and minimum daily air temperatures of 20.2 and $9.5^{\circ} \mathrm{C}$, respectively (Moonen et al., 2001). For both years, daily weather data were obtained from a meteorological station located within $100 \mathrm{~m}$ from the experimental fields.

In both years a full factorial of two durum wheat varieties, two $\mathrm{N}$ fertilisers before sowing, three topdressing $\mathrm{N}$ fertilisers and six split applications of $\mathrm{N}$ was replicated two times and arranged in a randomised, complete-block design. The durum wheat (Triticum durum Desf.) varieties were Latinur and Svevo, currently used in local production. The two $\mathrm{N}$ fertilisers before sowing were ammonium sulphate (AS), and urea containing the nitrification inhibitor 3,4-dimetihyl pyrazole phosphate (Entec ${ }^{\circledR} 46$ ). The three topdressing $\mathrm{N}$ fertilisers were AS, ammonium nitrate sulphate containing the nitrification inhibitor 3,4-dimetihyl pyrazole phosphate (Entec $\left.{ }^{\circledR} 26\right)$, and urea, and were applied at the 5th leaf unfolded stage. Total $\mathrm{N}$ amount of $180 \mathrm{~kg} \mathrm{ha}^{-1}$ was split among pre-seeding, at 5th leaf unfolded stage and at pseudo stem erection as follows: 0-180-0, 0-90-90, 30-150-0, 30-75-75, 60-120-0 and $60-60-60 \mathrm{~kg} \mathrm{Nha}^{-1}$. Growth stages of 5 th leaf unfolded and pseudo stem erection were individuated following the scale of Zadoks (Zadoks et al., 1974), corresponding respectively to GS15 and GS30.

Open-air lysimeter installation consisted of 144 lysimeters of $0.50-\mathrm{m}$ length, $0.50-\mathrm{m}$ width and $0.4-\mathrm{m}$ height (100-L volume), arranged in four rows of 36 , spaced $20 \mathrm{~cm}$ and embedded in expanded clay to smooth daily fluctuations in soil temperature. Lysimeters were filled with a soil tamped to about original soil bulk density, and were attached to a $3-\mathrm{cm}$ rigid PVC drain that ended in a central collection facility. Soil chemical-physical properties were: $68.5 \%$ sand $(2 \mathrm{~mm}>\varnothing>0.05 \mathrm{~mm}) ; 25.9 \%$ silt $(0.05 \mathrm{~m}>\varnothing>0.002 \mathrm{~mm}) ; 5.6 \%$ clay; $7.0 \mathrm{pH} ; 2.0 \%$ organic matter (Walkley and Black method); $0.8 \mathrm{~g} \mathrm{~kg}^{-1}$ total nitrogen (Kjeldahl method); $26.0 \mathrm{mg} \mathrm{kg}^{-1}$ available P (Olsen method); $76.3 \mathrm{mg} \mathrm{kg}^{-1}$ available $\mathrm{K}\left(\mathrm{BaCl}_{2}+\mathrm{TEA}\right.$ method $)$.

Phosphorus and potassium were hand applied preplanting as triple mineral phosphate and potassium sulphate at a rate of $150 \mathrm{~kg} \mathrm{ha}^{-1} \mathrm{P}_{2} \mathrm{O}_{5}$ and $150 \mathrm{~kg} \mathrm{ha}^{-1} \mathrm{~K}_{2} \mathrm{O}$. Nitrogen was hand applied before seeding and at GS15 according to the treatments and at GS30 as urea.

The durum wheat varieties, Latinur and Svevo, were sown on 18 November 2008 and 25 November 2009, within the optimum planting time for wheat production in Central Italy. A rate of 100 viable seeds per container, corresponding to 400 viable seeds $\mathrm{m}^{-2}$, in rows spaced $15 \mathrm{~cm}$ apart, was applied. Plant emergence was recorded on 5 December 2008 and 9 December 2009. Weed control was performed throughout wheat cycle by hand hoeing.

Leachates from each lysimeter were collected during the entire research period in both years after each major rainfall event in a 20-L PVC tank. Leachate volumes were measured and their $\mathrm{N}-\mathrm{NO}_{3}$ concentrations were determined with an Orion ion analyser model 502A (Orion Research Inc., Boston, MA, USA). Accumulated monthly leachate volumes were calculated and the monthly flow-weighted $\mathrm{N}-\mathrm{NO}_{3}$ concentrations were determined by summing up $\mathrm{N}-\mathrm{NO}_{3}$ mass collected for each rainfall event in a month divided by the total leachate volume collected in the month. Averagely, a concentration of $2.4 \mathrm{mg} \mathrm{N}-\mathrm{NO}_{3} \mathrm{~L}^{-1}$ was determined in rainfall. For all treatments, timing of stage of 1 st leaf emergence (GS10), 5th leaf unfolded (GS15), pseudo stem erection (GS30), inflorescence emergence (GS50), and physiological ripening (GS90) were recorded, expressing in thermal time the duration of the periods between stages (Table 1). Thermal time was calculated following McMaster and Wilhelm (1997), assuming $2{ }^{\circ} \mathrm{C}$ as base temperature (Porter and Gawith, 1999). At GS90 (22 June 2009 and 30 June 2010) plants from each container were manually cut at ground level and were partitioned into culms, leaves, chaff and grain. For dry weight 
Table 1

Accumulated growing degree days and rainfall during the whole wheat cycle and main growth periods. Growth stages are defined following Zadok's scale (GS00 seeding, GS10 emergence, GS15 5th leaf unfolded stage, GS30 pseudo stem erection, GS50 anthesis, GS 90 physiological maturity).

\begin{tabular}{lccccc}
\hline \multirow{2}{*}{ Period } & \multicolumn{2}{c}{ GDD $\left({ }^{\circ} \mathrm{C}\right)$} & & \multicolumn{2}{c}{ Rainfall $(\mathrm{mm})$} \\
\cline { 2 - 3 } \cline { 5 - 6 } & $2008-2009$ & $2009-2010$ & & $2008-2009$ & $2009-2010$ \\
\hline GS00-GS10 & 131.9 & 130.8 & & 169.2 & 52.4 \\
GS10-GS15 & 408.9 & 346.9 & & 206.4 & 254.8 \\
GS15-GS30 & 144.4 & 184.4 & & 80.0 & 58.8 \\
GS30-GS50 & 671.9 & 573.4 & & 220.6 & 100.0 \\
GS50-GS90 & 1048.7 & 1123.6 & & 69.6 & 259.8 \\
Whole cycle & 2405.7 & 2358.9 & & 745.8 & 725.8 \\
\hline
\end{tabular}

determination, samples from all plant parts were oven dried at $65^{\circ} \mathrm{C}$ up to constant weight. Mean kernel dry weight was also measured and number of kernels per unit area and harvest index (HI) were calculated. Samples of each plant part were analysed for nitrogen concentration (Kjeldahl method); $\mathrm{N}$ contents were calculated by multiplying $\mathrm{N}$ concentration by dry weight.

Nitrogen efficiency parameters were calculated for each treatment according to Moll et al. (1982) and López-Bellido et al. (2005). Nitrogen use efficiency $\left(\mathrm{kg} \mathrm{kg}^{-1}\right)$ was the ratio of grain yield biomass to $\mathrm{N}$ fertiliser. Nitrogen uptake efficiency (NUpE, $\mathrm{kg} \mathrm{kg}^{-1}$ ) was the ratio of total aerial plant part $\mathrm{N}$ uptake to $\mathrm{N}$ fertiliser. Nitrogen utilisation efficiency ( $\mathrm{NUtE}, \mathrm{kg} \mathrm{kg}^{-1}$ ) was the ratio of grain yield biomass to total $\mathrm{N}$ uptake. Nitrogen harvest index (NHI) was the ratio of $\mathrm{N}$ in grain to total $\mathrm{N}$ uptake.

Results were treated by ANOVA. The main effects of year, variety, $\mathrm{N}$ fertiliser before seeding, $\mathrm{N}$ fertiliser topdressing, $\mathrm{N}$ splitting, and their interactions were tested for dry weight of plant parts and relative $\mathrm{N}$ concentration and content and total $\mathrm{N}$ leached. The main effects of variety, $\mathrm{N}$ fertiliser before seeding, $\mathrm{N}$ fertiliser topdressing, $\mathrm{N}$ splitting, and their interactions were tested for drainage water, $\mathrm{N}$ concentration and $\mathrm{N}$ leaching in the months from November to April in the two seasons. The CoHort software package ver. 6.4 (CoHort software, Monterey, CA, USA) was used. Significantly different means were separated at the 0.05 probability level by the least significant difference test (Steel et al., 1997).

\section{Results}

\subsection{Weather conditions}

Total rainfall during wheat growing cycle was similar in the 2008-2009 and 2009-2010 growing seasons (Fig. 1 and Table 1) and was by $42 \%$ higher compared to the mean rainfall for the area over the last 10 years $(515 \mathrm{~mm})$. Rainfall from seeding to GS30 was similar in both years, accounting for over $50 \%$ of total rainfall during wheat cycle, whereas it differed during jointing and grain filling. During jointing, rainfall was about 3-fold in 2008-2009 compared to 2009-2010, while during grain filling it was about 3-fold in 2009-2010 compared to 2008-2009. Temperature was lower than the long-term average in both seasons, as the thermal time up to maturity was $2574^{\circ} \mathrm{C}$ in the long-term average, vs. $2406^{\circ} \mathrm{C}$ in $2008-2009$ and $2359^{\circ} \mathrm{C}$ in $2009-2010$ (Table 1). Differences between seasons in accumulated growing degree days were recorded only in the period from GS10 to GS50. The highest difference between seasons was recorded from GS15 to GS30, with $28 \%$ higher value in 2009-2010 compared to 2008-2009.

\subsection{Grain yield and yield components}

Grain yields were always higher in 2009-2010 crop season with all splittings. In both growing seasons the highest yield was
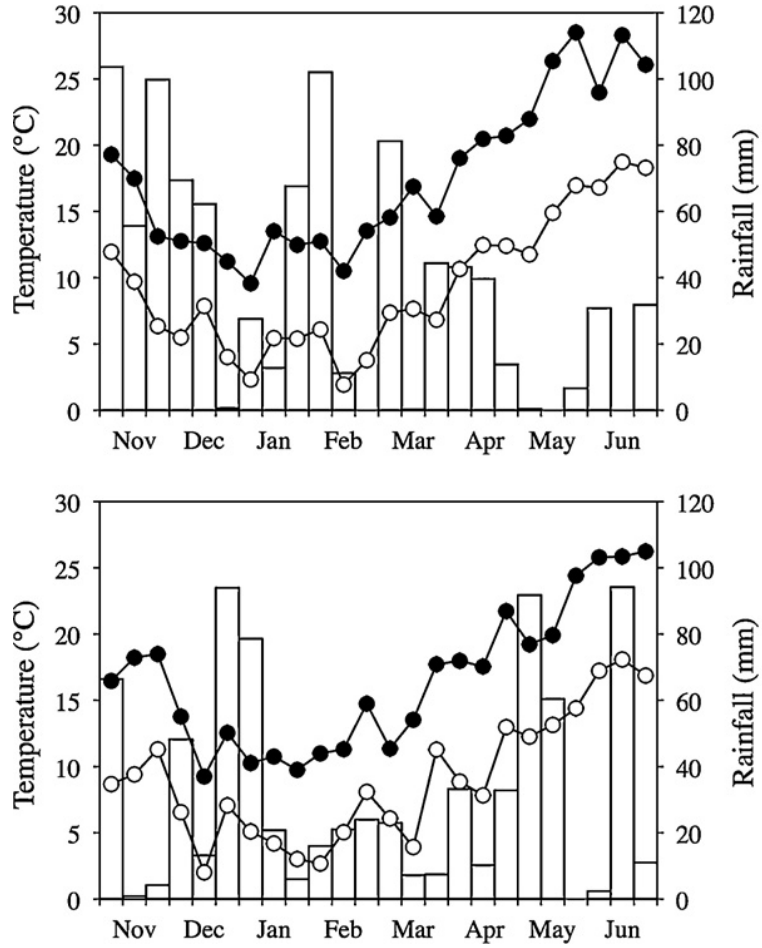

Fig. 1. Rainfall (bars), maximum (closed symbol) and minimum (open symbol) temperature in 2008-2009 (up) and 2009-2010 (down) seasons.

obtained with the 30-150-0 splitting, while the application of 0 180-0 in 2008-2009 and 60-120-0 in 2009-2010 resulted in the lowest grain yield (Fig. 2). Differences in grain yield between years and splittings were due to variations in number of spikes per unit area, number of kernels per spike and mean kernel weight. The average number of spikes $\mathrm{m}^{-2}$ was 559 in 2009-2010 season and 484 in 2008-2009 (results not shown) and was higher with 0-1800 and lowest with 60-60-60 (Table 2). The number of kernels per spike was higher in 2009-2010 only for the applications without $\mathrm{N}$ before seeding (0-180-0 and 0-90-90), while for the other four splittings it was the same in the two growing seasons (Fig. 2). In both years the highest values were recorded with 30-150-0, 60$60-60$ and $30-75-75$ splittings, and lowest with 0-180-0. Maximum variations due to different splittings were 8.4 kernels per spike in 2008-2009 and 6.1 kernels per spike in 2009-2010. Mean kernel weight did not vary between years while the highest values among nitrogen splittings were obtained by 30-75-75, 60-60-60 and 0-9090 treatments, and the lowest by 60-120-0 (Table 2). In summary, the highest grain yield obtained with the treatments 30-150-0 and 30-75-75 derived from the combination of low number of spikes, high number of kernels per spike and medium-high mean kernel weight. Conversely, the lowest grain yield recorded in the treatments $0-180-0$ in 2008-2009 and 60-120-0 in 2009-2010 were due

Table 2

Harvest index, spike number, and mean kernel weight. Nitrogen splitting mean values.

\begin{tabular}{llll}
\hline Nitrogen splitting & $\begin{array}{l}\text { Harvest } \\
\text { index }(\%)\end{array}$ & $\begin{array}{l}\text { Spike number } \\
\left(n \mathrm{~m}^{-2}\right)\end{array}$ & $\begin{array}{l}\text { Mean kernel } \\
\text { weight }(\mathrm{mg})\end{array}$ \\
\hline $0-180-0$ & $33.3 \mathrm{ab}$ & $595.6 \mathrm{~d}$ & $40.3 \mathrm{~b}$ \\
$0-90-90$ & $37.2 \mathrm{c}$ & $549.5 \mathrm{c}$ & $41.4 \mathrm{c}$ \\
$30-150-0$ & $35.8 \mathrm{bc}$ & $508.9 \mathrm{~b}$ & $40.2 \mathrm{~b}$ \\
$30-75-75$ & $37.6 \mathrm{c}$ & $494.9 \mathrm{ab}$ & $41.8 \mathrm{c}$ \\
$60-120-0$ & $31.9 \mathrm{a}$ & $509.4 \mathrm{~b}$ & $38.9 \mathrm{a}$ \\
$60-60-60$ & $36.3 \mathrm{bc}$ & $468.8 \mathrm{a}$ & $41.5 \mathrm{c}$ \\
\hline
\end{tabular}

Within columns, numbers followed by the same letter are not significantly different at $P \leq 0.05$. 
Table 3

Grain yield, vegetative dry weight, harvest index, spike number, kernel number and mean kernel weight. Variety and top dressing nitrogen fertilisers mean values.

\begin{tabular}{|c|c|c|c|c|c|c|}
\hline Treatments & Grain yield $\left(\mathrm{t} \mathrm{ha}^{-1}\right)$ & $\begin{array}{l}\text { Vegetative d.w. } \\
\left(\mathrm{tha}^{-1}\right)\end{array}$ & $\begin{array}{l}\text { Harvest } \\
\text { index (\%) }\end{array}$ & $\begin{array}{l}\text { Spike number } \\
\left(n \mathrm{~m}^{-2}\right)\end{array}$ & $\begin{array}{l}\text { Kernel number } \\
\left(n \text { spike }^{-1}\right)\end{array}$ & $\begin{array}{l}\text { Mean kernel } \\
\text { weight (mg) }\end{array}$ \\
\hline \multicolumn{7}{|l|}{ Variety } \\
\hline Latinur & $4.6 \mathrm{~b}$ & $8.2 \mathrm{~b}$ & $35.7 \mathrm{a}$ & $555.9 \mathrm{~b}$ & $20.2 \mathrm{a}$ & $41.9 \mathrm{~b}$ \\
\hline Svevo & $4.3 \mathrm{a}$ & $7.9 \mathrm{a}$ & $35.2 \mathrm{a}$ & $486.5 \mathrm{a}$ & $22.9 \mathrm{~b}$ & $39.4 \mathrm{a}$ \\
\hline \multicolumn{7}{|l|}{ Top dressing $\mathrm{N}$ fertiliser } \\
\hline Ammonium sulphate & $4.4 \mathrm{a}$ & $7.8 \mathrm{a}$ & $36.0 \mathrm{a}$ & $531 \mathrm{~b}$ & $20.6 \mathrm{a}$ & $40.5 \mathrm{a}$ \\
\hline Entec $^{\circledR} 26$ & $4.2 \mathrm{a}$ & $8.1 \mathrm{~b}$ & $33.9 \mathrm{a}$ & $517 \mathrm{a}$ & $21.2 \mathrm{ab}$ & $40.6 \mathrm{a}$ \\
\hline Urea & $4.7 \mathrm{~b}$ & $8.2 \mathrm{~b}$ & $36.4 \mathrm{a}$ & $516 a$ & $22.8 \mathrm{~b}$ & $41.0 \mathrm{a}$ \\
\hline
\end{tabular}

Within treatments variety and top dressing $\mathrm{N}$ fertiliser, numbers followed by the same letter are not significantly different at $P \leq 0.05$.

to the number of spikes that was medium, the number of kernels per spike and the mean kernel weight that were low-medium.

Grain yield of Latinur was, on average, by $7 \%$ higher than that of Svevo (Table 3). The increase was attributed to a higher number of spikes per unit area (+14\%), owing to a greater tillering rate, and mean kernel weight $(+6 \%)$. Conversely, number of kernels per spike of Svevo was by $13 \%$ higher.
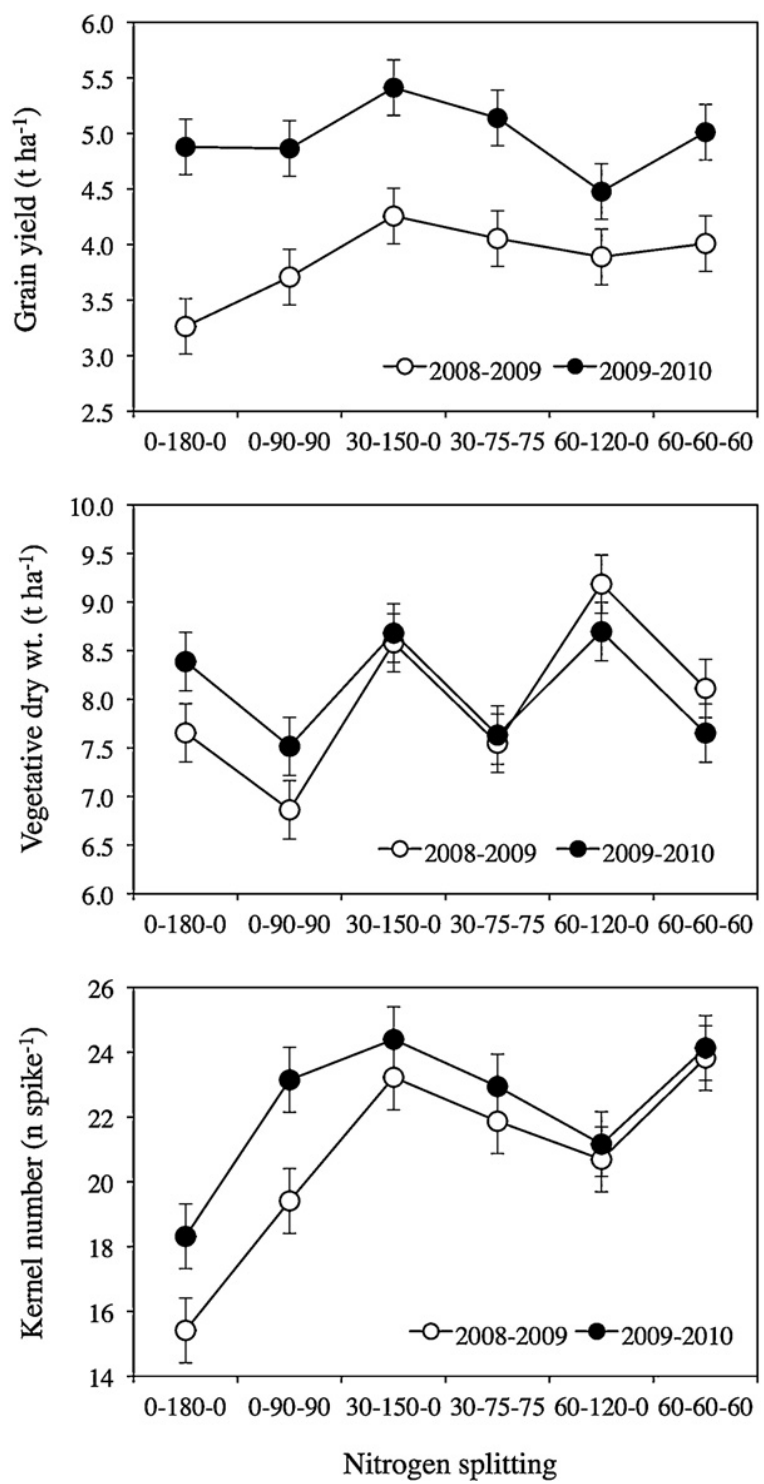

Fig. 2. Grain yield, vegetative dry weight and number of kernels per spike as affected by crop season $\times$ nitrogen splitting interaction. In these and in the following figures, error bars indicate LDS.
Grain yield was not affected by nitrogen source applied before seeding, but was mainly modified by topdressing $\mathrm{N}$ fertiliser. Yield increased by $0.4 \mathrm{tha}^{-1}$ with urea, compared to AS and Entec ${ }^{\circledR} 26$ average value, owing to a greater number of kernels per spike $(+9 \%)$ (Table 3).

The response of the vegetative plant part to the interaction year $\times$ splitting was different than the one of grain: dry weight was higher with 60-120-0 and 30-150-0 splittings and lower with 0-90-90 and 30-75-75 (Fig. 2). Differences between years were detected only with no $\mathrm{N}$ fertiliser before seeding, with higher values in 2009-2010 season. Dry weight of vegetative plant part was higher in Latinur than in Svevo and increased from AS to Entec ${ }^{\circledR} 26$ and urea (Table 3 ).

Harvest Index was by $17 \%$ higher in $2009-2010$ compared to 2008-2009 season and was modified by $\mathrm{N}$ splitting, being highest with 0-90-90 and 30-75-75 and lowest with 60-120-0 (Table 2). Differences in HI between varieties and top dressing $\mathrm{N}$ fertiliser were not statistically significant (Table 3 ).

\subsection{Nitrogen uptake}

Nitrogen concentration of grain and vegetative plant part were significantly affected only by the interaction year $\times \mathrm{N}$ splitting. The highest values were found with 0-90-90 and 30-75-75 in both seasons and with 0-180-0 in 2008-2009, and the lowest with 0$180-0,30-150-0$ in both seasons and with 60-120-0 in 2009-2010 (Fig. 3). Following the patterns of dry weight and $\mathrm{N}$ concentration, $\mathrm{N}$ content of grain and vegetative plant part were affected by the interaction year $\times \mathrm{N}$ splitting and by the mean effect of topdressing $\mathrm{N}$ fertiliser. Excluding the 60-120-0 split, the highest values of grain $\mathrm{N}$ content were recorded in 2009-2010 season at all splittings, but while in 2008-2009 differences among splittings were low (max. $18 \mathrm{~kg} \mathrm{~N} \mathrm{ha}^{-1}$ ), in 2009-2010 the splittings 0-90-90, 30$75-75$ and $60-60-60$ gave values by $28 \mathrm{~kg} \mathrm{~N} \mathrm{ha}^{-1}$ higher compared to the other splittings (Fig. 3). Grain N content increased from AS to Entec ${ }^{\circledR} 26(8.0 \%)$ and to urea (13.6\%), even though between these last two the non-significant increase due to the urea was of $5.1 \mathrm{~kg} \mathrm{~N} \mathrm{ha}^{-1}$ (Table 4). Differences for $\mathrm{N}$ content in vegetative plant part were also detected (Fig. 3 and Table 4). As a consequence, total $\mathrm{N}$ uptake by aerial plant part was by $34 \mathrm{~kg} \mathrm{~N} \mathrm{ha}^{-1}$ higher with $0-90$ $90,30-75-75$ and $60-60-60$ in 2009-2010 compared to the other

Table 4

Nitrogen content of grain and vegetative plant part. Top dressing nitrogen fertiliser mean values.

\begin{tabular}{lll}
\hline Top dressing N fertiliser & \multicolumn{2}{l}{ Nitrogen content $\left(\mathrm{kg} \mathrm{ha}^{-1}\right)$} \\
\cline { 2 - 3 } & Grain & Vegetative plant part \\
\hline Ammonium sulphate & $92.1 \mathrm{a}$ & $36.9 \mathrm{ab}$ \\
Entec $^{\circledR} 26$ & $99.5 \mathrm{ab}$ & $34.8 \mathrm{a}$ \\
Urea & $104.6 \mathrm{~b}$ & $37.8 \mathrm{~b}$
\end{tabular}

Within columns, numbers followed by the same letter are not significantly different at $P \leq 0.05$. 

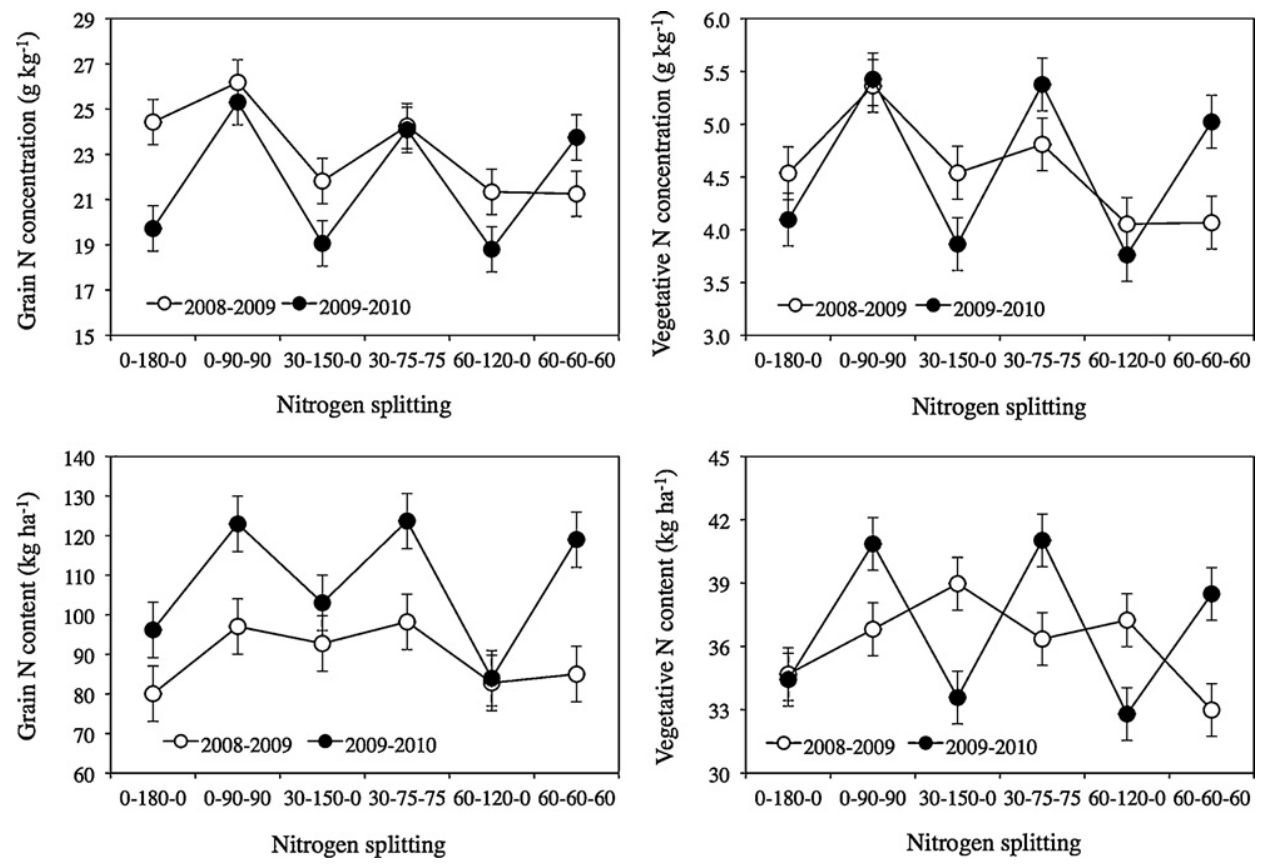

Fig. 3. Nitrogen concentration and content of grain and vegetative plant part as affected by crop season $\times$ nitrogen splitting interaction.

splittings (Fig. 3) and by $13 \mathrm{~kg} \mathrm{Nha}^{-1}$ higher with urea compared to AS (Table 4 ). NUE was affected by the interaction year $\times$ splitting, and had the same pattern of grain yield, being the rate of fertiliser $\mathrm{N}$ the same for all treatments (Table 5). Similarly to grain yield, highest NUE was achieved in both year with the 30-150-0 and 3075-75 splittings. The season influenced also NUpE and NUtE. In 2008-2009 variations due to split treatments on both indices were inconsistent, while in 2009-2010 NUpE increased appreciably with treatments involving higher $\mathrm{N}$ rates at GS30 (0-90-90, 30-75-75 and 60-60-60), while NUtE was higher when higher $\mathrm{N}$ rates were applied at GS15 (0-180-0, 30-150-0 and 60-120-0) (Table 5). The proportion of total plant $\mathrm{N}$ in the seeds at maturity (NHI) was lowest when the second topdressing fertilisation was not applied (Fig. 4).

\subsection{Nitrogen leaching}

The amount of drainage water recorded in the months from November to April was not affected by any of the tested treatments, but was higher during the 2008-2009 crop season $(430.3 \mathrm{~mm})$ compared to the $2009-2010$ season $(389.9 \mathrm{~mm}$ ). Highest percolations occurred in December 2009 and in December and January

Table 5

Nitrogen use efficiency (NUE), nitrogen uptake efficiency (NUpE) and nitrogen utilisation efficiency (NUtE). Season $\times$ nitrogen splitting interaction.

\begin{tabular}{lllll}
\hline Season & N splitting & $\begin{array}{l}\text { NUE } \\
\left(\mathrm{kg} \mathrm{kg}^{-1}\right)\end{array}$ & $\begin{array}{l}\text { NUpE } \\
\left(\mathrm{kg} \mathrm{kg}^{-1}\right)\end{array}$ & $\begin{array}{l}\text { NUtE } \\
\left(\mathrm{kg} \mathrm{kg}^{-1}\right)\end{array}$ \\
\hline $2008-2009$ & $0-180-0$ & $18.1 \mathrm{a}$ & $0.64 \mathrm{a}$ & $28.4 \mathrm{ab}$ \\
& $0-90-90$ & $20.6 \mathrm{~b}$ & $0.74 \mathrm{bc}$ & $27.7 \mathrm{a}$ \\
& $30-150-0$ & $23.6 \mathrm{~cd}$ & $0.73 \mathrm{bc}$ & $32.3 \mathrm{~cd}$ \\
& $30-75-75$ & $22.5 \mathrm{bc}$ & $0.75 \mathrm{c}$ & $30.1 \mathrm{abc}$ \\
& $60-120-0$ & $21.6 \mathrm{bc}$ & $0.67 \mathrm{abc}$ & $32.4 \mathrm{~cd}$ \\
& $60-60-60$ & $22.3 \mathrm{bc}$ & $0.66 \mathrm{ab}$ & $34.0 \mathrm{~d}$ \\
& & & & \\
& $0-180-0$ & $27.1 \mathrm{f}$ & $0.73 \mathrm{bc}$ & $37.4 \mathrm{e}$ \\
& $0-90-90$ & $27.0 \mathrm{ef}$ & $0.91 \mathrm{~d}$ & $29.7 \mathrm{abc}$ \\
& $30-150-0$ & $30.1 \mathrm{~g}$ & $0.76 \mathrm{c}$ & $39.6 \mathrm{e}$ \\
& $30-75-75$ & $28.6 \mathrm{fg}$ & $0.91 \mathrm{~d}$ & $31.2 \mathrm{bcd}$ \\
& $60-120-0$ & $24.9 \mathrm{de}$ & $0.65 \mathrm{ab}$ & $38.3 \mathrm{e}$ \\
& $60-60-60$ & $27.8 \mathrm{f}$ & $0.87 \mathrm{~d}$ & $31.8 \mathrm{~cd}$ \\
\hline
\end{tabular}

Within columns, numbers followed by the same letter are not significantly different at $P \leq 0.05$.

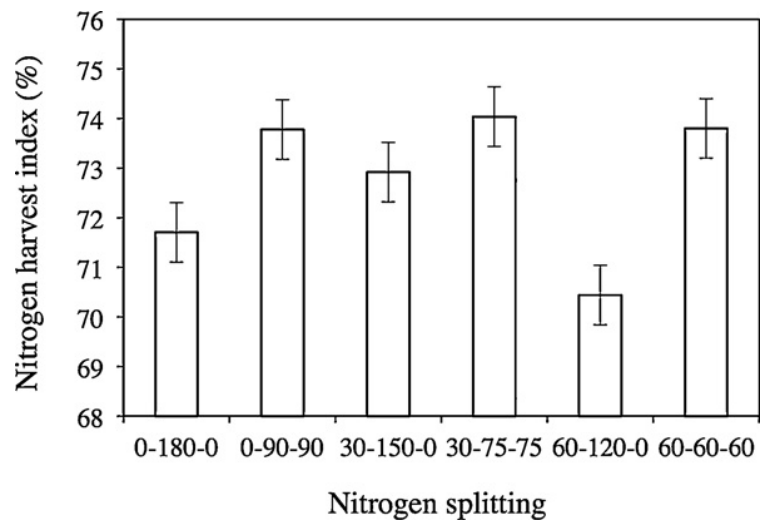

Fig. 4. Nitrogen harvest index as affected by nitrogen splitting mean effect.

2010 (Fig. 5). High rainfall determined high drainage few days following pre seeding $\mathrm{N}$ application in the 2008-2009 season, while in 2009-2010 drainage started about one month following $\mathrm{N}$ application. In November, December and January, drainage water accounted for $61 \%$ and $80 \%$ of total drainage, respectively in

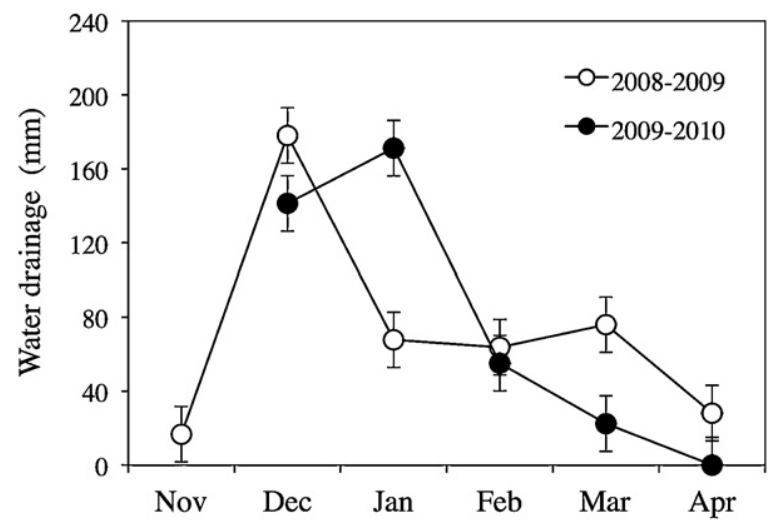

Fig. 5. Drainage water during wheat cycle as affected by crop season mean effect. 

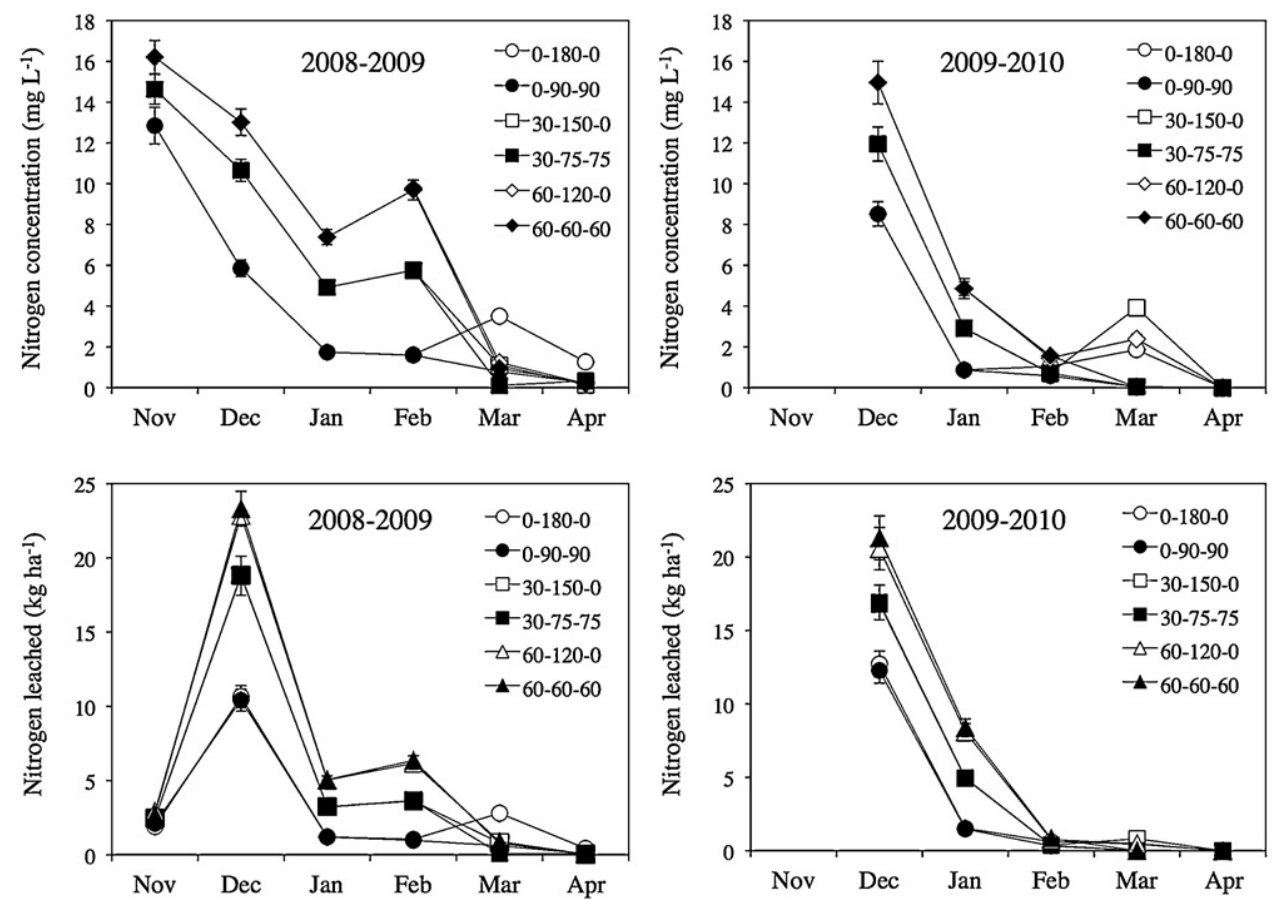

Fig. 6. Nitrogen concentration in drainage and nitrogen leached during 2008-2009 and 2009-2010 seasons as affected by nitrogen splitting mean effect.

2008-2009 and 2009-2010 seasons. The amount of drainage water was close to zero following the second top dressing fertilisation.

In both seasons, nitrogen concentration in drainage water and leached $\mathrm{N}$ were affected only by $\mathrm{N}$ splitting. Nitrogen concentration in water was higher following seeding and decreased until January in both years at all splittings (Fig. 6). In this period, N concentration increased with the increase of $\mathrm{N}$ rate before seeding. Thereafter, values were lower than $4 \mathrm{mg} \mathrm{N} \mathrm{L}^{-1}$ and unaffected by $\mathrm{N}$ splitting.

Averaged over all treatments, total amount of $\mathrm{N}$ lost with drainage water during wheat cycle was almost entirely accounted for $\mathrm{N}$ leaching in December (63\% and $74 \%$ of the total leached N, respectively in the 2008-2009 and 2009-2010 seasons) (Fig. 6). In the period following first topdressing $\mathrm{N}$ distribution, $\mathrm{N}$ leached accounted for $17 \%$ and $4 \%$ of total N lost respectively for $2008-2009$ and 2009-2010 seasons. The quantity of $\mathrm{N}$ lost in both years increased with the increase of $\mathrm{N}$ rate applied before seeding, while topdressing fertiliser did not affect losses (Fig. 7). When $\mathrm{N}$ was not applied before seeding, $\mathrm{N}$ lost was low and similar in the two seasons, while with the other splittings N lost was higher in 2008-2009 compared to 2009-2010 season.

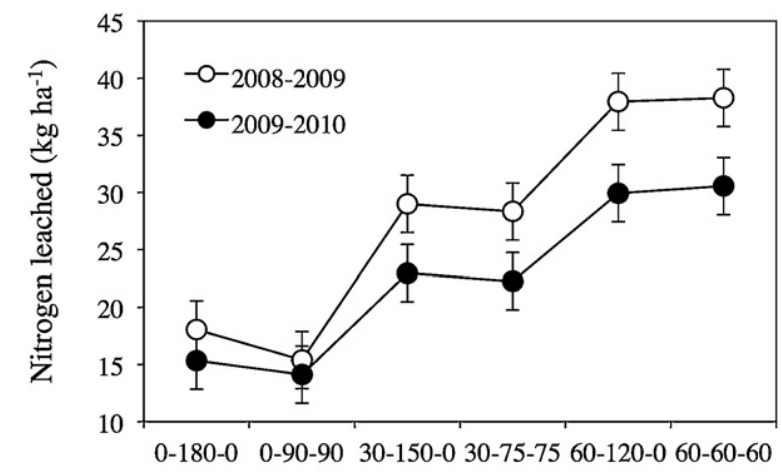

Nitrogen splitting

Fig. 7. Total N leached during 2008-2009 and 2009-2010 seasons as affected by nitrogen splitting mean effect.

\section{Discussion}

\subsection{Nitrogen fertiliser at sowing}

The application of SA and Entec ${ }^{\circledR} 46$ before seeding did not modify either grain yield and yield components or $\mathrm{N}$ uptake and leaching, indicating that in this research the inclusion of the nitrification inhibitor did not show any advantage in comparison with ammonium fertiliser. Nitrification inhibitors have been shown to increase yield when the fertiliser is applied in conditions that favour nitrate losses by leaching, that is, in periods of high rainfall or irrigation, or in sandy or highly permeable soils (Prasad and Power, 1995; Barth et al., 2001). Conversely, in other studies the yield advantage was null or small, averaging just $5 \%$, due to the application of $\mathrm{N}$ when leaching was low and when crop demand was high (Hergert and Wiese, 1980; Pasda et al., 2001; Arregui and Quemada, 2006, 2008). In this research, the application of the nitrification inhibitor was performed when leaching was high and crop demand was low, which are conditions that would favour the inclusion of nitrification inhibitors in fertiliser. Nevertheless nitrification inhibitor was not successful to control nitrate leaching during the period of high rainfall.

\subsection{Nitrogen splitting}

Climatic conditions during growing season influenced wheat grain yield, as in the 2008-2009 the average grain yield was by $22 \%$ lower than in 2009-2010. The high yield in 2009-2010 was due to higher number of spikes and greater spike size, probably because of good growing conditions during initial stages of crop development that favoured the development of tillers and promoted the floret fecundation, resulting in higher number of kernels per spike. Fertiliser splitting in both years had a considerable impact on grain yield and yield components. The observed differences in grain yield and yield components caused by the interactive effects of different $\mathrm{N}$ splittings and weather conditions may be due to processes in soil and in plant affecting $\mathrm{N}$ availability in critical phases of determination of yield components. Owing to the scheme of treatments (equal 
total $\mathrm{N}$ rate, but different splittings) the effect of the different rates in different phases cannot be separated in our results, and attempts to clarify causes can only be considered as possible reasons. Nevertheless, it was demonstrated that it is possible to improve grain yield and $\mathrm{N}$ concentration by variations in split applications of fertiliser $\mathrm{N}$ : the variations due to splitting reached $1 \mathrm{t}$ in grain yield while the protein grain content increased by $4 \%$, corresponding to $7 \mathrm{~g} \mathrm{~kg}^{-1}$ in $\mathrm{N}$ concentration of grain. Comparing the effect of all splittings, the highest grain yield (and NUE) and the highest protein concentration (and NUpE) were obtained with 30-150-0 and 30-75-75 treatments, respectively. The yield advantage was related to the higher number of kernels per spike resulting from the higher number of differentiated spikelets per spike. Thus, the application of $30 \mathrm{~kg} \mathrm{~N} \mathrm{ha}^{-1}$ before seeding is required to have high grain yield, as mineral $\mathrm{N}$ in soil deriving from mineralisation of soil organic matter and not leached probably was not sufficient to ensure high yield. The other characters were differently affected by differential $\mathrm{N}$ availability during crop growth, as yield components varied among split treatments in the two seasons. The application of N only topdressing (0-180-0 and 0-90-90) greatly reduced grain yield by the reduction of the number of kernels per spike. The effect was particularly heavy in the season with high rainfall before seeding, when the mineral $\mathrm{N}$ amount present in the soil at the time of fertiliser application was very low owing to $\mathrm{N}$ leaching. In the treatment 0-180-0 high $\mathrm{N}$ rate at GS15 stimulated tillering, but $\mathrm{N}$ deficiency occurred during the last part of wheat cycle (N applied at GS15 was probably immobilised into soil and not available thereafter). Nitrogen restriction during the last part of wheat cycle (0-180-0, 30-150-0, 60-120-0) lead to a reduced $\mathrm{N}$ accumulation into grain, and for $60-120-0$ also a reduction of carbohydrate accumulation into grain. This means that grain growth was probably constrained by $\mathrm{N}$ shortage during grain filling. Since $\mathrm{N}$ leaching increased with the increase of the rate of $\mathrm{N}$ applied before seeding, it is likely that the lower yield with $60-120-0$ compared to $0-180-0$ is due to lower $\mathrm{N}$ availability due to $\mathrm{N}$ leached.

In summary, the application of $\mathrm{N}$ only topdressing is not a valid option since soil mineral $\mathrm{N}$ is not sufficient to sustain $\mathrm{N}$ uptake in the first three months of crop growth, when rainfall and consequently $\mathrm{N}$ leaching are high. Conversely, the application of the highest rate $\left(60 \mathrm{~kg} \mathrm{Nha}^{-1}\right)$ before seeding is not to be recommended, since it poses serious environmental concerns owing to high risk of leaching losses. Moreover, the application of $\mathrm{N}$ in two rates before seeding and topdressing at early crop stages is also not advisable, since dry matter and $\mathrm{N}$ accumulation into grain is reduced. The splitting of the $\mathrm{N}$ rate in three amendments instead of two with the third application at later crop stage lead to an increase of grain protein content, suggesting an improvement of grain quality parameters.

\subsection{Top dressing nitrogen fertilisers}

N source applied top dressing at GS15 affected grain yield and yield components, as well as dry weight of vegetative plant part and $\mathrm{N}$ uptake. Conversely, $\mathrm{N}$ leaching was not affected as the weather conditions and the crop evapotranspiration following fertiliser application did not promote $\mathrm{NO}_{3}{ }^{-}$leaching. Indeed, water drainage was closely related to rainfall, which was negligible in the period following top dressing $\mathrm{N}$ application. The application of urea resulted in the highest grain yield, owing to a greater number of kernels per spike that compensated the lower number of spikes per unit area. In durum wheat, spike initiation occurs in the period from the development of the 4th leaf, GS14, to stem elongation, GS (Arduini et al., 2009) and the number of initiated spikelets is enhanced in presence of a good $\mathrm{N}$ availability in soil (Masoni et al., 2001). Our results suggest that the prompter release of $\mathrm{N}$ from urea compared to AS and Entec ${ }^{\circledR} 26$ increased $N$ available in the period of floret initiation and differentiation. Mulvaney (1994) showed that nitrification occurred in the order urea $>$ AS. Likewise, Eno and Blue (1957) and Martikainen (1985) reported that urea nitrifies faster than AS. This differential in nitrification rate has been attributed in part to the increase in soil $\mathrm{pH}$ associated with the hydrolysis of urea soon after application, in contrast to the decline in soil $\mathrm{pH}$ associated with the application of AS (Lindsay et al., 1962; Allred and Ohlrogge, 1964). The effect of Entec ${ }^{\circledR} 26$ on grain yield and yield components was similar to that of AS, thus the delayed effect of the nitrification inhibitor DMPP on $\mathrm{NH}_{4}{ }^{+}$nitrification did not benefit wheat growth. Entec ${ }^{\circledR} 26$ contains 7.5\% $\mathrm{NO}_{3}-\mathrm{N}$ and $18.5 \% \mathrm{NH}_{4}-\mathrm{N}$, while AS contains all nitrogen in $\mathrm{NH}_{4}{ }^{+}$form. The probable higher persistence of $\mathrm{NH}_{4}{ }^{+}$in soil in Entec ${ }^{\circledR} 26$ than in AS plots had not any advantage for crop growth and the reduction of $\mathrm{N}-\mathrm{NO}_{3}$ due to the inhibition of nitrification in Entec ${ }^{\circledR} 26$ compared to AS is probably compensated by the presence of nitric $\mathrm{N}$. In addition, we cannot exclude that part of $\mathrm{NH}_{4}^{+}$may be fixed in clay minerals (Gioacchini et al., 2006), thus reducing $\mathrm{N}$ availability to plants.

\section{Conclusions}

Our results evidenced no clear advantage of the distribution to durum wheat of Entec ${ }^{\circledR} 46$ before seeding, and Entec ${ }^{\circledR} 26$ topdressing, neither in terms of increased grain quantity and quality, nor in terms of higher $\mathrm{N}$ utilisation efficiency and decreased $\mathrm{N}$ leaching. Since $\mathrm{N}$ fertiliser application represents an important cost in crop production and fertilisers containing the nitrification inhibitor DMPP have higher prices than SA or urea, their use is not advisable in Central Italy. Further researches should investigate the application to durum wheat of other delayed-release $\mathrm{N}$ fertilisers, focussing on the mechanisms of $\mathrm{N}$ release in field conditions, in order to synchronise it with plant demand.

The splitting of $\mathrm{N}$ fertiliser is crucial to improve fertiliser use efficiency and to increase grain yield and grain protein concentration. The application of $30 \mathrm{~kg} \mathrm{Nha}^{-1}$ before seeding is recommended, since mineralisation of soil organic matter could not ensure adequate mineral $\mathrm{N}$ availability for initial crop development, resulting in a great reduction of kernel number per spike and consequently grain yield. Conversely, $60 \mathrm{~kg} \mathrm{Nha}^{-1}$ before seeding proved to exceed crop needs, resulting in increased $\mathrm{N}$ leaching during initial crop stage and $\mathrm{N}$ deficiency at later crop development. Topdressing distribution can be recommended both entirely at 5th leaf or splitted half at 5 th leaf and half at stem elongation. In our research, the first splitting, i.e. 30-150-0, gave the highest grain yield while the second, 30-75-75, gave the highest $\mathrm{N}$ concentration in grain. Finally, the distribution of urea at 5 th leaf is advisable because, compared to ammonium sulphate and Entec ${ }^{\circledR} 26$, it turned into higher grain yield with lower distribution costs.

\section{References}

Alcoz, M.M., Hons, F.M., Haby, V.A., 1993. Nitrogen fertilization timing effect on wheat production, nitrogen uptake efficiency, and residual soil nitrogen. Agronomy Journal 85, 1198-1203.

Allred, S.E., Ohlrogge, A.J. 1964. Principles of nutrient uptake from bands. VI. Germination and emergence of corn as affected by ammonia and ammonium phosphate. Agronomy Journal 56, 309-313.

Arduini, I., Ercoli, L., Mariotti, M., Masoni, A., 2009. Sowing date affect spikelet number and grain yield of durum wheat. Cereal Research Communications 37 469-478.

Arregui, L.M., Quemada, M., 2006. Drainage and nitrate leaching in a crop rotation under different $\mathrm{N}$-fertilizer strategies: application of capacitance probes. Plant and Soil 288, 57-69.

Arregui, L.M., Quemada, M., 2008. Strategies to improve nitrogen use efficiency in winter cereal crops under rainfed conditions. Agronomy Journal 100, 277-284.

Ayoub, M., Guertin, S., Fregeau-Reid, J., Smith, D.L., 1994. Nitrogen fertilizer effect on breadmaking quality of hard red spring wheat in eastern Canada. Crop Science 34, 1346-1352. 
Barth, G., von Tucher, S., Schmidhalter, U., 2001. Influence of soil parameters on the effect of 3,4-dimethylpyrazole-phosphate as a nitrification inhibitor. Biology and Fertility of Soils 34, 98-102.

Bouwman, A.F., Boumans, L.J.M., Batjes, N.H., 2002. Estimation of global $\mathrm{NH}_{3}$ volatilization loss from synthetic fertilizers and animal manure applied to arable lands and grasslands. Global Biogeochemical Cycles 16, 1024-1037.

Carreres, R., Sendra, J., Ballesteros, R., Valiente, E.F., Quesada, A., Carrasco, D., Leganés, F., Cuadra, J.G., 2003. Assessment of slow release fertilizers and nitrification inhibitors in flooded rice. Biology and Fertility of Soils 39, 80-87.

Cartagena, M.C., Vallejo, A., Diez, J.A., Bustos, A., Caballero, R., Roman, R., 1995. Effect of the type of fertilizer and source of irrigation water on $\mathrm{N}$ use in a maize crop. Field Crops Research 44, 33-39.

Delogu, G., Cattivelli, L., Pecchioni, N., De Falcis, D., Maggiore, T., Stanca, A.M., 1998. Uptake and agronomic efficiency of nitrogen in winter barley and winter wheat. European Journal of Agronomy 9, 11-20.

Diez, J.A., Roman, R., Caballero, R., Caballero, A., 1997. Nitrate leaching from soils under a maize-wheat-maize sequence, two irrigation schedules and three types of fertilisers. Agriculture, Ecosystems \& Environment 65, 189-199.

Dilz, K., 1988. Efficiency of uptake and utilization of fertilizer nitrogen by plants. In: Jekinson, D.S., Smith, K.A. (Eds.), Nitrogen Efficiency In Agricultural Soils. Elsevier Applied Science, London, pp. 1-26.

Eno, C.F., Blue, W.G., 1957. The comparative rate of nitrification of anhydrous ammonia, urea, and ammonium sulfate in sandy soils. Soil Science Society of America Proceedings 21, 392-396.

Ercoli, L., Arduini, I., Mariotti, M., Lulli, L., Masoni, A., 2012. Management of sulphur fertiliser to improve durum wheat production and minimise $S$ leaching. European Journal of Agronomy 38, 74-82.

Fuertes-Mendizábal, T., Aizpurua, A., González-Moro, M.B., Estavillo, J.M., 2010. Improving wheat breadmaking quality by splitting the $\mathrm{N}$ fertilizer rate. European Journal of Agronomy 33, 52-61.

Garrido-Lestache, E., López-Bellido, R.J., López-Bellido, L., 2004. Effect of N rate, timing and splitting and $\mathrm{N}$ type on bread-making quality in hard red spring wheat under Mediterranean conditions. Field Crops Research 85, 213-236.

Garrido-Lestache, E., López-Bellido, R.J., López-Bellido, L., 2005. Durum wheat quality under Mediterranean conditions as affected by $\mathrm{N}$ rate, timing and splitting, $\mathrm{N}$ form and $\mathrm{S}$ fertilization. European Journal of Agronomy 23, 265-278.

Gioacchini, P., Ramieri, N.A., Montecchio, D., Marzadori, C., Ciavatta, C., 2006. Dynamics of mineral nitrogen in soils treated with slow-release fertilizers. Communications in Soil Science and Plant Analysis 37, 1-12.

Hergert, G.W., Wiese, R.A., 1980. Performance of nitrification inhibitors in the Midwest (west). In: Meisinger, J.J., Randall, G.W., Vitosh, M.L. (Eds.), Nitrification Inhibitors: Potentials and Limitations, vol. 38. Am. Soc. Agron., Madison, WI, pp. 89-105 (Spec. Publ.)

Kaiser, E.A., Eiland, F., Germon, J.C., Heinermeyer, R.O., Henault, C., Lind, A.M., Maag, M., Saguer, E., Van Cleemput, O., Vermoesen, A., Webster, C., 1996. What predicts nitrous oxide emissions and denitrification $\mathrm{N}$-loss from European soils? Zeitschrift für Pflanzenernahrungund Bodenkunde 159, 541-547.

Lindsay, W.L., Frazier, A.W., Stephenson, H.F., 1962. Identification of reaction products from phosphate fertilizers in soils. Soil Science Society of America Proceedings 26, 446-452.
López-Bellido, L., López-Bellido, R.J., Redondo, R., 2005. Nitrogen efficiency in wheat under rainfed Mediterranean conditions as affected by split nitrogen application. Field Crops Research 94, 86-97.

López-Bellido, L., Muñoz-Romero, V., Benítez-Vega, J., Fernández-García, P. Redondo, R., López-Bellido, R.J., 2012. Wheat response to nitrogen splitting applied to a vertisols in different tillage systems and cropping rotations under typical Mediterranean conditions. European Journal of Agronomy 43, 24-32.

Martikainen, P.J., 1985. Nitrification in forest soil of different $\mathrm{pH}$ as affected by urea, ammonium sulphate and potassium sulphate. Soil Biology and Biochemistry 17 , 363-367.

Masoni, A., Arduini, I., Mariotti, M., Ercoli, L., Bonari, E., 2001. Number of spikelets and leaf appearance rate in durum wheat as affected by temperature, daylength and nitrogen availability. Agricoltura Mediterranea 130, 57-65.

McMaster, G.S., Wilhelm, W.W., 1997. Growing degree-days: one equation, two interpretations. Agricultural and Forest Meteorology 87, 291-300.

Melaj, M.A., Echeverría, H.E., López, S.C., Studdert, G., Andrade, F., Bárbaro, N.O., 2003. Timing of nitrogen fertilization in wheat under conventional and no-tillage system. Agronomy Journal 95, 1525-1531.

Moll, R.H., Kamprath, E.J., Jackson, W.A., 1982. Analysis and interpretation of is factors which contribute to efficiency of nitrogen utilization. Agronomy Journal 74, 562-564.

Moonen, C., Masoni, A., Ercoli, L., Mariotti, M., Bonari, E., 2001. Long-term changes in rainfall and temperature in Pisa, Italy. Agricoltura Mediterranea 131, 11-22.

Mulvaney, R.L 1994 Nitrification of different nitrogen fertilizers. In: Hoeft, R.G (Ed.), Illinois Fertilizer Conference Proceedings. Cooperative Extension Service, University of Illinois, Urbana, IL, pp. 83-96.

Ottman, M.J., Doerge, T.A., Martin, E., 2000. Durum grain quality as affected by nitrogen fertilization near anthesis and irrigation during grain fill. Agronomy Journal $92,1035-1041$.

Pasda, G., Hahndel, R., Zerulla, W., 2001. Effect of fertilizers with the new nitrification inhibitor DMPP (3,4-dimethylpyrazole phosphate) on yield and quality of agricultural and horticultural crops. Biology and Fertility of Soils 34, 85-97.

Porter, J.R., Gawith, M., 1999. Temperatures and the growth and development of wheat: a review. European Journal of Agronomy 10, 23-36.

Prasad, R., Power, J.F., 1995. Nitrification inhibitors for agriculture, health, and the environment. Advances in Agronomy 54, 233-281.

Raun, W.R., Solie, J.B., Taylor, R.K., Arnall, D.B., Mack, C.J., Edmonds, D.E., 2008. Ramp calibration strip technology for determining midseason nitrogen rates in corn and wheat. Agronomy Journal 100, 1088-1093.

Raun, W.R., Johnson, G.V., 1999. Improving nitrogen use efficiency for cereal production. Agronomy Journal 91, 357-363.

Sowers, K.E., Miller, B.C., Pan, W.L., 1994. Optimizing yield and grain protein in soft white winter wheat with split nitrogen applications. Agronomy Journal 86 , 1020-1025.

Steel, R.G.D., Torrie, J.H., Dickey, D.A., 1997. Principles and Procedures of Statistics: A Biometrical Approach. McGraw-Hill, New York.

Strong. W.M., 1995. Nitrogen fertilization of upland crops. In: Bacon, P.E.(Ed.), Nitrogen Fertilization in the Environment. Marcel Dekker, New York, pp. 129-169.

Zadoks, J.C., Chang, T.T., Konzak, C.F., 1974. A decimal code for the growth stages of cereals. Weed Research 14, 415-421. 